\title{
Association Between Hyperlipidemia and Mammographic Breast Density in Post-menopausal Women
}

\author{
Mehmet Akif Öztürk, (ㄷ) Mustafa Keçeci, (1) Sabiha Kömoğlu, (1) Müzeyyen Eryılmaz, \\ (1) Yaşar Sertbaş, (1) Meltem Sertbaş, (1) Ali Özdemir
}

Department of Internal Medicine, Fatih Sultan Mehmet Training and Research Hospital, İstanbul, Turkey

Submitted: 15.05.2018 Accepted: 28.05.2018

Correspondence: Mehmet Akif Öztürk Fatih Sultan Mehmet Eğitim ve Araştırma Hastanesi, İç Hastalıkları Kliniği, İstanbul, Turkey

E-mail: akifozturk@hotmail.com
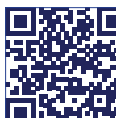

Keywords: Density; hyperlipidemia; mammography.

\begin{abstract}
Objective: Breast cancer is the most common cancer type in women. High mammographic breast density is associated with an increased risk of breast cancer in women. The goal of this study was to investigate a possible association between mammographic breast density and hyperlipidemia.
\end{abstract}

Methods: This retrospective study was conducted using the records of patients from between January and December of 2016 who met the inclusion criteria: postmenopausal women between the ages of 50 and 65 years who did not have diabetes mellitus and who had a contemporaneous digital mammography performed and had the appropriate laboratory data. A total of 164 women were included.

Results: The mean age of the patients was $55.88 \pm 4.49$ years. According to the Breast Imaging Reporting and Data System, II 6 of the 164 patients $(70.7 \%)$ were in the low-density group, and 28 patients $(20.3 \%)$ were categorized as having a high-density result. The group with a high mammographic breast density had a significantly greater high-density lipoprotein $(\mathrm{HDL})$ cholesterol level than the group with a low breast density $(55.35 \pm 12.98$ vs $5 \mathrm{I} .14 \pm 12.38 \mathrm{mg} / \mathrm{dL}$, respectively; $\mathrm{p}=0.035$ ). The low-density lipoprotein cholesterol level of the high-density tissue group was greater than that of the low-density group, but was not statistically significant ( $446.5 \pm 37.22$ vs $133.73 \pm 33.97 \mathrm{mg} / \mathrm{dL}$, respectively; $\mathrm{p}=0.052)$.

Conclusion: It was determined that a high HDL cholesterol level and older age were associated with breast density. There is a need for prospective, large-scale studies in this area.

\section{INTRODUCTION}

Breast cancer is the most common cancer type in women. [1] The incidence was identified as $24.1 / 100,000$ in a study conducted in 1997 in Turkey. ${ }^{[2]}$ Unfortunately, it is known that this incidence is increasing. ${ }^{[3]}$ Although it remains the second leading cause of cancer deaths, it is one of the screenable types of cancer seen in women. ${ }^{[l]}$ Screening programs increase the detection rate of clinically untreated early-stage breast cancers. ${ }^{[4]}$ Mammography is the most usable screening tool for breast cancer. The American Cancer Society recommends annual screening with digital mammography for women aged between 45 and 54 years, and biennially after 55 years of age, as long as the woman is in good health. ${ }^{[5]}$
Greater mammographic breast density is associated with an increased risk of breast cancer in women. ${ }^{[6-8]}$ There are few studies about an association between hyperlipidemia and mammographic breast density in the medical literature. The aim of this research was to investigate a relationship between mammographic breast density and hyperlipidemia.

\section{MATERIAL AND METHODS}

This retrospective study was conducted with the records of patients from between January and December of 2016 who met the inclusion criteria. Postmenopausal women between the ages of 50 and 65 years who did not have diabetes mellitus and who had a contemporaneous digi- 
tal mammography performed and who had the appropriate laboratory data in their records were included in the study. The mammographic examinations were performed using a GE Apollon 2004 digital mammography device (GE Healthcare, Inc. Chicago, IL, USA). Both breasts were evaluated with mediolateral oblique and craniocaudal projection. The patients were grouped according to the Breast Imaging Reporting and Data System (BIRADS) as low mammographic density (A: predominantly fatty, B: scattered fibroglandular densities), or high mammographic density (C: heterogeneously dense, D: extremely dense). Laboratory parameters of triglycerides, low-density lipoprotein (LDL) and high-density lipoprotein (HDL) cholesterol, fasting blood glucose, glycated hemoglobin ( $\mathrm{HbAlc}$ ), calcium, and $25 \mathrm{OH}$ vitamin $\mathrm{D}$, as well as demographic data were collected from patient electronic records. The $25 \mathrm{OH}$ vitamin $D$ value was determined using the chemiluminescent microparticle immunoassay method with an Abbott i2000 device (Abbott Diagnostics, Lake Forest, IL, USA). The HbAlc measurement was performed with a Tosoh g8 model high performance liquid chromatography analyzer (Tosoh Bioscience, Tokyo, Japan), and other biochemical parameters were measured with an Abbott cl6200i Architect photometric device (Abbott Diagnostics, Lake Forest, IL, USA).

Patients with known breast cancer or breast surgery for any reason were excluded from the present research. This study was performed with the approval of the scientific board of Fatih Sultan Mehmet Education and Research Hospital (approval number: 17073/17-050.99, dated March 27, 2017).

IBM SPSS Statistics for Windows, Version 22.0 (IBM Corp., Armonk, NY, USA) was used for the statistical analysis. Mean \pm SD was used for descriptive and continuous variables, and frequency and percent were used for categorical variables. Parameters with a normal distribution were compared with Student's t-test, and parameters with abnormal distribution were compared using the Mann-Whitney $U$ test. $A$ chi-square test was used to compare qualitative data. $\mathrm{P}<0.05$ was considered statistically significant.

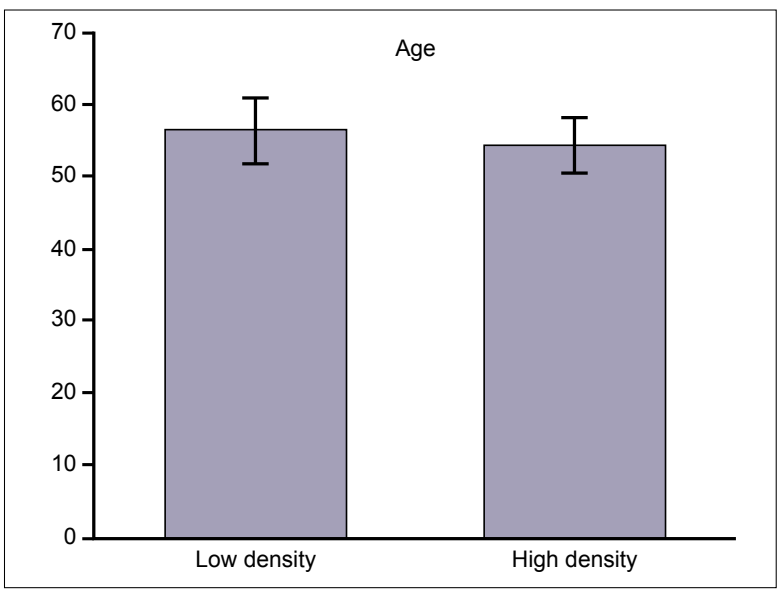

Figure 1. Mean ages of low density group and high density group.

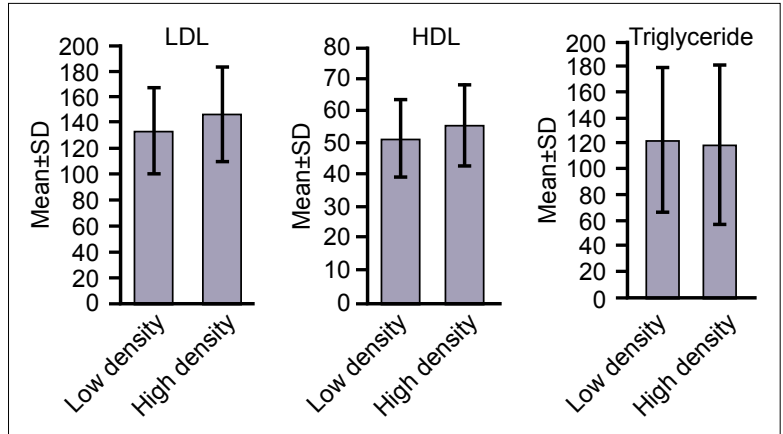

Figure 2. The mean levels of triglyceride, LDL and HDL cholesterol.

\section{RESULTS}

A total of 164 women who met the study criteria were included in the study. The mean age of the patients was $55.88 \pm 4.49$ years. According to the BIRADS, 116 of the 164 patients $(70.7 \%)$ were classified as having low mammographic breast density, and 28 patients $(20.3 \%)$ were in the high-density group. Patients in the low-density group were older than those in the high-density group $(56.49 \pm 4.60$ vs $54.39 \pm 3.85$ years, respectively; $p=0.003$ ) (Fig. I). The levels of $\mathrm{HbAlc}$, fasting blood sugar, calcium, and $25-\mathrm{OH}$ vitamin

Table I. Glucose, glycated hemoglobin, calcium, and $25-\mathrm{OH}$ vitamin D levels of the low and high mammographic breast density groups

\begin{tabular}{|c|c|c|c|}
\hline & Low-density & High-density & $\mathbf{p}$ \\
\hline & Mean \pm SD & Mean \pm SD & \\
\hline Glucose (mg/dL) & $99.34 \pm 11.46$ & $97.06 \pm 11.82$ & ${ }^{\prime} 0.254$ \\
\hline Glycated hemoglobin (\%) & $5.7 \pm 0.36$ & $5.69 \pm 0.33$ & '0.846 \\
\hline Calcium (median) (mg/dL) & $9.67 \pm 1.76(9.5)$ & $9.47 \pm 0.6(9.6)$ & ${ }^{2} 0.759$ \\
\hline $25-\mathrm{OH}$ vitamin $\mathrm{D}$ (median) $(\mathrm{ng} / \mathrm{mL})$ & $19.13 \pm 14.61(13)$ & $19.82 \pm 12.8(15)$ & ${ }^{2} 0.505$ \\
\hline
\end{tabular}

'Student's t-test; ${ }^{2}$ Mann-Whitney $U$ test; $p>0.05$. SD: Standard deviation. 
Table 2. Cholesterol and triglyceride levels of the low and high mammographic breast density groups

\begin{tabular}{|c|c|c|c|}
\hline & Low-density & High-density & $\mathbf{p}$ \\
\hline & Mean \pm SD & Mean $\pm S D$ & \\
\hline High-density lipoprotein cholesterol (mg/dL) & $51.14 \pm 12.38$ & $55.35 \pm 12.98$ & ${ }^{\prime} 0.035^{*}$ \\
\hline Low-density lipoprotein cholesterol (mg/dL) & $133.73 \pm 33.97$ & $146.5 \pm 37.22$ & '0.052 \\
\hline Triglyceride (mg/dL) (median) & $123.01 \pm 57.35(105.5)$ & $119 \pm 62.74(109)$ & 20.658 \\
\hline
\end{tabular}

D were not statistically significant between the 2 groups (Table I). The group with a high mammographic breast density had a significantly higher HDL cholesterol level than the low-density group $(55.35 \pm 12.98$ vs $51.14 \pm 12.38 \mathrm{mg} / \mathrm{dL}$, respectively; $p=0.035)$. The $L D L$ cholesterol level of the high-density tissue group was greater than that of the lowdensity group, but the difference was not statistically significant (I $46.5 \pm 37.22$ vs $133.73 \pm 33.97 \mathrm{mg} / \mathrm{dL}$, respectively; $p=0.052$ ). There was no statistically significant difference between the mean triglyceride values of the 2 groups. The mean and median levels of triglyceride and LDL and HDL cholesterol are presented in Table 2 and Figure 2.

\section{DISCUSSION}

Screening with mammography is recommended for all women with an average breast cancer risk. Magnetic resonance imaging and ultrasound are the other screening modalities available. They are more useful for further research, especially for high-risk women. A new metaanalysis has demonstrated that breast cancer mortality is reduced with mammography screening. ${ }^{[9]}$ In a study conducted with 4257 women in Turkey between 2009 and 2010 , detection rates of stage I invasive breast cancer and carcinoma in situ were found higher in mammographic screening program. ${ }^{[4]}$

There are many risk factors for breast cancer, such as early menarche, ${ }^{\left[{ }^{10]}\right.}$ late menopause, ${ }^{\left[{ }^{[1]}\right]}$ ionizing radiation to the chest area at a young age, ${ }^{[12]}$ use of estrogen-containing medication, ${ }^{[13]}$ previous breast cancer (contralateral breast), ${ }^{[14]}$ age, ${ }^{[1]}$ and breast density. ${ }^{[6-8]}$

Breast density reflects the proportion of fibroglandular and connective tissue in the breast to fat tissue. Mammography can help to detect the density of the breasts. It is now common to use the BIRADS to classify breast density. ${ }^{[15]}$ There are 4 density categories used by radiologists according to this classification system: A: predominantly fatty (0$25 \%$ dense), B: scattered fibroglandular densities (25-50\% dense), C: heterogeneously dense (5I-75\% dense) and D: extremely dense ( $>75 \%$ dense). In our study, we grouped patients as having a low density $(0-50 \%)$ or a high density $(>50 \%)$.
There are limited data on an association between hyperlipidemia and breast density in the literature, and the results are inconsistent. Caglayan et al. ${ }^{[16]}$ found no relationship between lipid parameters and breast density in a study of 215 postmenopausal women, of whom 40 were classified as having dense tissue and 175 were categorized as having non-dense breast tissue. An association between mammographic density and some anthropometric and biochemical parameters, such as age, body mass index, cholesterol levels, and transaminases, was reported by jihyekim et al. ${ }^{[17]}$ Boudreau et al. ${ }^{[18]}$ found a correlation between statin usage and high mammographic breast density in their study, and Wei et al. ${ }^{[19]}$ reported that women who had a breast cancer diagnosis had a higher LDL-cholesterol and triglyceride level and a lower HDL-cholesterol level than the healthy control group in their study.

We found that the HDL-cholesterol level was significantly greater in the high-density breast group than in the low-density group. Although statistical significance was not reached, the LDL-cholesterol level was also greater in the group with more density. These results were consistent with the results reported by Ji-hyekim et al. ${ }^{[17]}$ We also found that the low-density breast tissue group was older than the highdensity group. The increase in adipose tissue with age may be related to the reduction of density. Modifiable dietary factors, such as caloric intake and olive oil consumption, may also be associated with mammographic density.

A relationship between mammographic breast density and some medications has also been investigated. Bershteĭn et al. ${ }^{[20]}$ analyzed the influence of metformin and $\mathrm{N}$-acetylcysteine on mammographic breast density and found that both agents decreased breast density independently of insulin use. Further research of the effects of metformin and other antidiabetic medications on breast density may provide data supporting the use of metformin in cancer prevention, as it may have a protective effect in breast cancer.

This was a retrospective study. We could not get any information on body mass index or past drug use, especially hormone replacement therapy, from the existing patient records. Another limitation was that our sample size was small. 


\section{CONCLUSION}

In conclusion, we found that a higher HDL cholesterol level and older age were associated with greater breast density. There is a need for prospective, large-scale studies in this area.

Ethics Committee Approval

Approved by the scientific board of Fatih Sultan Mehmet Education and Research Hospital (approval number: 17073 | 17-050.99, dated March 27, 2017).

Informed Consent

Retrospective study.

Peer-review

Internally peer-reviewed.

Authorship Contributions

Concept: M.A.O., Y.S.; Design: A.O., Y.S.; Data collection \&/or processing: M.K., M.S., M.E., S.K.; Analysis and/ or interpretation: M.K., M.E., S.K., M.S.; Literature search: M.A.O.; Writing: M.A.O.; Critical review: A.O., M.A.O.

Conflict of Interest

None declared.

\section{REFERENCES}

1. Siegel RL, Miller KD, Jemal A. Cancer Statistics, 2017. CA Cancer J Clin 2017;67:7-30. [CrossRef]

2. Fidaner C1, Eser SY, Parkin DM. Incidence in Izmir in 1993-1994: first results from Izmir Cancer Registry. Eur J Cancer 2001;37:8392. [CrossRef]

3. Özmen V. Breast cancer in the world and Turkey. J Breast Health 2008;4:6-12.

4. Kayhan A, Gurdal SO, Ozaydin N, Cabioglu N, Ozturk E, Ozcinar B, et al. Successful first round results of a Turkish breast cancer screening program with mammography in Bahcesehir, Istanbul. Asian Pac J Cancer Prev 2014;15:1693-7. [CrossRef]

5. Oeffinger KC, Fontham ET, Etzioni R, Herzig A, Michaelson JS, Shih YC, et al; American Cancer Society. Breast Cancer Screening for Women at Average Risk: 2015 Guideline Update From the American Cancer Society. JAMA 2015;314:1599-614. [CrossRef]

6. Saftlas AF, Hoover RN, Brinton LA, Szklo M, Olson DR, Salane $\mathrm{M}$, et al. Mammographic densities and risk of breast cancer. Cancer 1991;67:2833-8. [CrossRef]
7. Boyd NF, Byng JW, Jong RA, Fishell EK, Little LE, Miller AB, et al. Quantitative classification of mammographic densities and breast cancer risk: results from the Canadian National Breast Screening Study. J Natl Cancer Inst 1995;87:670-5. [CrossRef]

8. Byrne C, Schairer C, Wolfe J, Parekh N, Salane M, Brinton LA, et al. Mammographic features and breast cancer risk: effects with time, age, and menopause status. J Natl Cancer Inst 1995;87:1622-9. [CrossRef]

9. Marmot MG, Altman DG, Cameron DA, Dewar JA, Thompson SG, Wilcox M. The benefits and harms of breast cancer screening: an independen retrieved no results. Lancet 2012;380:1778-86. [CrossRef]

10. Colditz GA, Rosner B. Cumulative risk of breast cancer to age 70 years according to risk factor status: data from the Nurses' Health Study. Am J Epidemiol 2000;152:950-64. [CrossRef]

11. Ritte R, Lukanova A, Tjønneland A, Olsen A, Overvad K, Mesrine $\mathrm{S}$, et al. Height, age at menarche and risk of hormone receptorpositive and -negative breast cancer: a cohort study. Int J Cancer 2013;132:2619-29. [CrossRef]

12. Henderson TO, Amsterdam A, Bhatia S, Hudson MM, Meadows AT, Neglia JP, et al. Systematic review: surveillance for breast cancer in women treated with chest radiation for childhood, adolescent, or young adult cancer. Ann Intern Med 2010;152:444-55. [CrossRef]

13. Clemons M, Goss P. Estrogen and the risk of breast cancer. N Engl J Med 2001;344:276-85. [CrossRef]

14. Nichols HB, Berrington de González A, Lacey JV Jr, Rosenberg PS, Anderson WF. Declining incidence of contralateral breast cancer in the United States from 1975 to 2006. J Clin Oncol 2011;29:1564-9.

15. American College of Radiology. American College of Radiology Breast Imaging Reporting and Data System BI-RADS, 5th ed, D'Orsi CJ, Sickles EA, Mendelson EB, Morris EA, (Eds), American Colege of Radiology, Reston, VA 2013.

16. Caglayan EK, Caglayan K, Alkis I, Arslan E, Okur A, Banli O, et al. Factors Associated with Mammographic Density in Postmenopausal Women.J Menopausal Med 2015;21:82-8. [CrossRef]

17. Kim JH, Lee HK, Cho JH, Park HK, Yang HJ. Correlations between female breast density and biochemical markers. J Phys Ther Sci 2015;27:2097-100. [CrossRef]

18. Boudreau DM, Rutter CM, Buist DS. The influence of statin use on breast density. Cancer Epidemiol Biomarkers Prev 2006;15:1026-9.

19. Wei LJ, Zhang C, Zhang H, Wei X, Li SX, Liu JT. A case-control study on the association between serum lipid level and the risk of breast cancer. Zhonghua Yu Fang Yi Xue Za Zhi 2016;50:1091-5. [Article in Chinese]

20. Bershtein LM, Vasil'ev DA, Kovalenko IG, Poroshina TE, Kisel'nikov KS, Boiarkina MP, et al. The influence of metformin and $\mathrm{N}$-acetylcysteine on mammographic density in postmenopausal women. Vopr Onkol 2012;58:45-9. [Article in Russian] 
Post-menopozal Kadınlarda Hiperlipidemi ve Mamografik Meme Yoğunluğu Arasındaki İlişki

Amaç: Meme kanseri, kadınlarda en sık görülen kanser türüdür. Yüksek mamografik meme yoğunluğu, kadınlarda meme kanserine yakalanma riski ile ilişkilidir. Bu çalışmada mamografik meme yoğunluğu ve hiperlipidemi arasındaki olası ilişkiyi araştırmayı amaçladık.

Gereç ve Yöntem: Bu geriye dönük çalışma Ocak-Aralık 2016 arasında dahil edilme kriterlerini karşılayan hastalarda yapıldı. Çalışmaya diabetes mellitus tanısı konmayan, eş zamanlı dijital mamografı ve uygun laboratuvar verileri olan, 50-65 yaş arası post-menopozal kadınlar dahil edildi. Çalışma kriterlerini karşılayan toplam 164 kadın çalışmaya alındı.

Bulgular: Hastaların yaş ortalaması 55.88 $\$ 4.49$ yıldı. BIRADS (Breast Imaging Reporting and Data System) sistemine göre 164 hastanın II6'sı (\%70.7) düşük yoğunlukta, 28'i (\%20.3) yüksek yoğunluklu gruptaydı. Yüksek yoğunluklu grup düşük yoğunluklu gruba göre yüksek yoğunluklu lipoprotein (HDL) kolesterol düzeyini anlamlı derecede daha yüksek (sırasıyla, $55.35 \pm 12.98$ ve $51.14 \pm 12.38 \mathrm{mg} / \mathrm{dL}, \mathrm{p}=0.035$ ) idi. Yüksek yoğunluklu grubun düşük yoğunluklu lipoprotein (LDL) kolesterol düzeyi, düşük yoğunluklu gruptan daha yüksekti, ancak istatistiksel olarak anlamlı değildi (sırasıyla, I $46.5 \pm 37.22$ ve $133.73 \pm 33.97 \mathrm{mg} / \mathrm{dL}, \mathrm{p}=0.052$ ).

Sonuç: Çalışmamızda daha yüksek HDL kolesterol ve ileri yaşın artmış meme yoğunluğu ile ilişkili olduğunu tespit ettik. Bu alanda ileriye dönük ve büyük ölçekli çalışmalara ihtiyaç vardır.

Anahtar Sözcükler: Hiperlipidemi; mamografi; yoğunluk. 